\title{
The Impact of Corporate Social Responsibility (CSR) on Organization Profitability
}

\author{
Emezi, Charles Nwaneri ${ }^{1}$ \\ ${ }^{1}$ Federal Polytechnic Nekede, Imo State, Nigeria \\ Correspondence: Emezi Charles Nwaneri, Evening Programme Directorate, Federal Polytechnic Nekede, P. M. B. \\ 1036 Owerri, Imo State, Nigeria. Tel: 234-706-431-6640. E-mail: charlesemezi@yahoo.com
}

Received: June 3, 2015

Accepted: June 20, 2015

Online Published: August 22, 2015

doi:10.5539/ijbm.v10n9p60

URL: http://dx.doi.org/10.5539/ijbm.v10n9p60

\begin{abstract}
The research on "the impact of corporate social responsibility (CSR) on organizational profitability" seeks to enrich our understanding of CSR as strategic tool for achieving organization competitive advantage and profitability. The study made use of Profit after Tax and investment in CSR data which are secondary data from Nigerian Breweries PLC and Lafarge Africa PLC annual reports as of 2005-2014. The data collected were analyzed using simple regression, coefficient of correlation $(R)$, and coefficient of determination $\left(R^{2}\right)$. The study revealed that, there is positive correlation between CSR investments and organizational profitability. It is recommended that, organization management should formulate and implement their CSR program in consultation with its stakeholders.
\end{abstract}

Keywords: corporate social responsibility, corporate social philanthropy, profitability, strategy and sustainable

\section{Introduction}

\subsection{Background of the Study}

Corporate Social Responsibility (CSR) is taking the center stage in organization, it strategic important as a strategic tool for creating sustainable value is being acknowledged by organizations. Creating value is not the problem in organization but sustaining those values over a longer period is the problem. Sustainable values are values which an organization can create and maintain over a long period without affecting the ability of the organization to meet and address his future needs.

But organizations, are not embracing the idea of CSR, but prefer Corporate Social Philanthropy (CSP). According Amaeshi (2011), he established that organization continue emphasis or embracing of CSP, is given CSR agenda a poor characterization, negative reputations and disparagement in the boardrooms. Therefore, CSR is mostly classified as an extra cost. If avoided by organizations is understandable and natural thing to do.

Avoiding the concept (corporate social responsibility), over the years by organizations has not position them strategically in the market. Providing or donating funding to schools, prisons etc. are great effort and contributions. But addressing the negative effect of their operations on the stakeholders, by establishing a framework structure designed to meet the present and future negative effect of the organization operation. A good example is the effect of oil spillage and gas frying by oil and gas companies operating in the Niger-Delta region of Nigeria which resulted into loss of aquatic lives, land degradation and health issues. The oil companies rely on government through her Ministry of Environment to clear-up the environment but forget government constant cry for lack of fund and the bureaucratic structure of the civil servant which takes longer time to approve any project.

This complete dependence on government has it turn on their operations as the host communities have to result to jungle justices to press home their charges. We know the story too well. But the losses to the nation and oil companies will have been avoided if they have not embarked on corporate social philanthropy; given money to chiefs, kings, politicians, bribery, youth leaders and even the security operatives. These are all corporate social philanthropy with no result in the long-run.

Long-run profitability and growth is the key to ensure the continued existence of organizations in a competitive market environment. 


\subsection{Problem Identification}

The concept of CSR has still not gain wide acceptance as a strategic tool for gaining competitive advantage in organization and therefore ensure long-run profitability and growth. But most executives accept CSR as a tactical public relation (PR) tool, with emphases on short-run profitability and PR.

In the name of CSR they embark on corporate social philanthropy, wasting the limited available organization resources on short-term objectives which have no strategic impact on the organization mission. At the end of all the PRs, the organizations are not profitably position in the long-run. A living illustration is the Niger-Delta region crises in Nigeria.

Corporate social philanthropy does not have a long term market value on the organization mission. The paper therefore seeks to exploit if CSR has a significant relationship with organization profitability.

The result will assist in the building of acceptability of CSR as a strategic tool for achieving organization mission.

\subsection{Objectives of the Study}

1). To evaluate the role of Corporate Social Responsibility in gaining competitive advantage to the organization.

2). To understand if there is correlation between corporate social responsibility and organization profitability.

\subsection{Research Hypothesis}

Ho: there is no positive correlation between corporate social responsibility and organization profitability.

\subsection{Scope of the Study}

CSR is a vast topic which cannot be fully covered in a single report, with respect to this; the research will restrict the study to controllable proportions by concentrating on breweries and cement industry, using Nigerian Breweries PLC and Lafarge Africa PLC.

\section{Literature Review}

\subsection{Meaning Corporate Social Responsibility}

According to Agulanna and Madu (2008) reporting Mondy and Premeaux (1993), define corporate social responsibility as the "implied, enforced or felt obligation of managers, acting in their official capacity, to serve or protect the interests of groups other than themselves".

UNIDO (2002), in their report, present three definition of CSR from various international organizations and two of the definitions presented:

"Being socially responsible means not only fulfilling legal expectations, but also going beyond compliance and investing more into human capital, the environment and relations with stakeholders." (The European Commission)

"Operating a business in a manner that meets or exceeds the ethical, legal, commercial and public expectations that society has of business." (Business for Social Responsibility).

\subsection{Drivers of Corporate Social Responsibility}

In 2002 United Nations Industrial Development Organization (UNIDO) report, they identify the basic drivers of CSR as: values, strategy and public pressure.

1). Values: Organizations are no longer making profit maximization their sole aim of being in business, they now recognizes the needs to address the negative impact of their operations on their stakeholder and sustainable development.

2). Strategy: An organization strategy is a function of various factors which are internal and external to the organization. A company actual strategy is made-up of the planned strategy and unplanned strategy. CSR activities help in strategic development, deployment and control.

3). Public Pressure: Public opinion is not making it easy for corporations to operate "business as usual". Any act of failure on organization CSR; may led to the public opinions calling for stiffer laws and organized movement against the organization.

One or the combinations of these drivers influence organization CSR activities.

\subsection{Orientations of Corporate Social Responsibility}

Corporations are not fully aware of the orientations of CSR, they believe is all about giving back to the 
community and contributing to the social development of their stakeholders. CSR goes beyond the ideas of donations and guided corporate bribing to strategically positioning the organization as a responsible corporate citizen. The orientations of CSR are:

1) Profitability Orientation: This holds that an organization is socially responsible if it makes profit for its owners (shareholders) and thereby achieves other corporate objectives which are tie to its profitability potentials. Profit maximization is not only an economic activities, it is equally a social activity. The research is directed to understand the effect of the organization social behavior on their profitability.

2) Trusteeship Orientation: The organization is a trustee of the society resources committed to them and used by them to achieve their objective. This orientation holds that, there is a social contract between the organization and the various stakeholders where they operate. Social contract is a web of responsibility between all stakeholders in a sector to interact and co-exist for the better good of all parties and future generations.

3) Quality of Life: Whatsoever be the nature of the firm operations, in the course of achieving their objectives, they must understand that all stakeholders no matter his economic and social standing have an undeniable right to quality of life (quality of life refers to the general well-being of a society in terms of freedom, education, health care, safety, free-time, etc.). So in the process of achieving your objectives, the definition of sustainable development must be kept in mind and must not be compromised.

"Development which meets the needs of the present without compromising the ability of future generation to meet their own needs".

\subsection{Principles of Corporate Social Responsibility}

1) Sustainability: This principle established that, the organization should carry out CSR programs or projects which it can sustainably carry over time and in line with the definition of sustainable development. According to Growther and Aras (2010), sustainability "is concerned with the effect which action taken in the present has upon the option available in future".

2) Accountability: The organization must recognize that they are responsible to the external stakeholders and accountable to them in the process of achieving their objective. Therefore organization must assume the responsibility of their action. The organization is at the central of the social contract; they are not only responsible to the owners of the business but to all parties to the social contract and therefore should be held accountable for their actions.

3) Transparency: Organizations must maintain an easy to read and understand objectives on every area of their activities. All stakeholders should be able to see through the organization activities through their policies and demand for explanations when noticed they are drifting away from the policy. The external stakeholders are the worst hit of the organization negative activities (externalities), so they have the right to know what the organization is doing for itself and for them.

\subsection{Corporate Social Responsibility and Profitability}

There is a growing acceptance that profits and broader values and principles can go hand in hand:

"We believe that our commitment to contribute to sustainable development holds the key to our long-term business success. "[Shell International] NUIDO (2002).

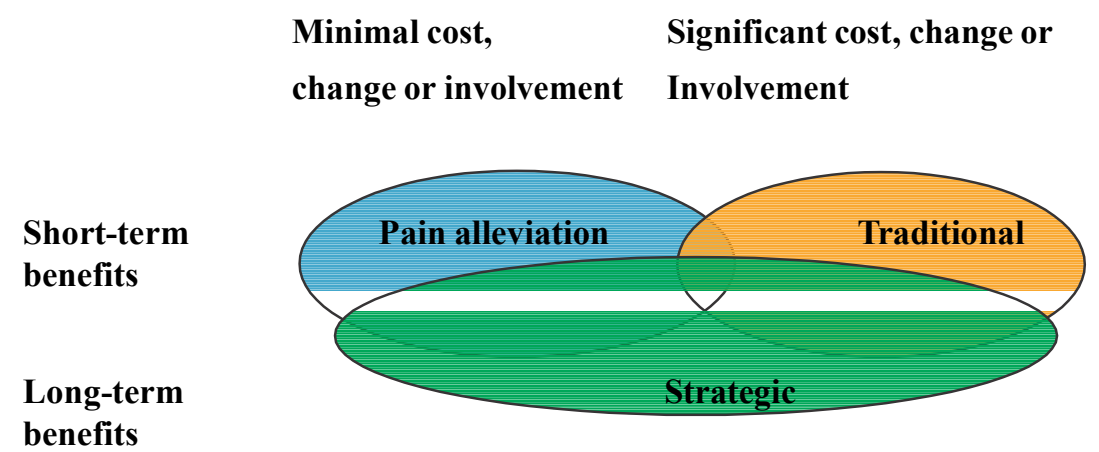

Figure 1. Balancing short-term with long-term business benefits

Source: NUIDO (2002). 
1) Pain alleviation/ Reputation protection: Engaging in CSR, in the short run help to protect the organization from financial losses that may result from product boycott and bad reputation. The reputation of an organization is all it has and any positive step taken to protect it can't be monetized.

2) Cost advantage: The cost saved from constructive customer complains which helps in innovation and productivity. This narrows the research and development effort of organization, to the specific needs of the customers saving billions of naira.

3) Strategic: The strategic aspect of CSR is to synchronize the organization short and long term vision into one sustainable direction. Dynamic organizations do not only change with the customers, but initial the change from her CSR activities.

Other benefits of CSR to organizations are:

- Savings from operational cost

- Good corporate image

- Increased ability to attract and retain qualify staff

- Better relations with government

- Sharper anticipation and management of risk

- $\quad$ Learning and innovation

2.6 The case against Corporate Social Responsibility

"The role of well-run companies is to make profits, not save the planet. Let them not make the error of confusing the two" Wolf (2001).

CSR has not have it all the ways as there are authorizes questioning the involvement of organizations in CSR. They believe that if organization should involve in CSR it will affect their focus on the primary reasons they were employ "profit maximization".

Milton Friedman argued that managers that, take the shareholders fund to address social needs is basically stealing from the corporation. And Agulanna and Madu (2008) said that funds spend on CSR cannot be easily accounted for by managers, which makes it very difficult to audit CSR account.

The major opponents of CSR constantly hold that the primary purpose of business is to make profit and this should not be confused for any purpose. And managers are trained to make profit and ensure the continued survival of the business.

Holding fast to this argument in this highly dynamic business environment of today faced with emerging competitors (markets) in Asia, Africa and the rest of the world, is voluntarily filling for liquidation and bankruptcy.

NUIDO (2002) report, established the strategic approach to avoid these pitfalls, it state that: CSR initiatives, which aim to hold business to account, need to be:

- Based on a legitimate standard-setting and oversight process that involves the diverse range of stakeholders from outside the business world.

- Backed up by robust processes of measurement and reporting. Measures that demonstrate the social, environmental and economic impact of a company's activities.

- Built on a strong business case, which aligns CSR with business success but that recognizes the potential trade-offs between social, environmental and economic factors.

- Flexible enough to allow business to innovate; solve problems and develop opportunities.

\section{Data Presentation and Analysis}

\subsection{Analysis of the Information}

The study covers the period, 2005-2014 while adopting the ordinary least square simple regression models as the main statistical tool of analysis. Here the profit after tax (PAT) is used as the dependent variable for the simple regression models; it is regressed on the corresponding figures for corporate social responsibility cost (CSR-K) as explanatory variables.

The study employed only secondary data from the annual reports of Nigerian Breweries PLC and Lafarge Africa PLC these are presented in Table 1 and Table 2 respectively. The test statistic includes therefore, coefficient of 
correlation (R), and coefficient of determination $\left(\mathrm{R}^{2}\right)$.

The data collection instrument is from two different unrelated industries. The purpose is to establish if there is any correlation between profitability and CSR in the industries.

Table 1. Nigerian Breweries Plc PAT and CSR-K in Naira

\begin{tabular}{lll}
\hline YEAR & PAT & CSR-K \\
\hline 2005 & $8,254,557,000$ & $60,133,050$ \\
2006 & $10,900,524,000$ & $25,321,540$ \\
2007 & $18,942,856,000$ & $44,942,024$ \\
2008 & $25,700,593,000$ & $27,633,908$ \\
2009 & $27,910,091,000$ & $100,517,175$ \\
2010 & $30,332,118,000$ & $67,123,955$ \\
2011 & $38,408,847,000$ & $40,400,000$ \\
2012 & $38,042,714,000$ & $81,674,450$ \\
2013 & $43,080,349,000$ & $207,193,655$ \\
2014 & $42,520,253,000$ & $140,203,543$ \\
\hline
\end{tabular}

Source: Annual reports.

Table 2. Lafarge Africa Plc PAT and CSR-K in Naira

\begin{tabular}{lll}
\hline YEAR & PAT & CSR-K \\
\hline 2005 & $2,763,164,000$ & $38,900,000$ \\
2006 & $10,677563,000$ & $65,035,000$ \\
2007 & $11,178,866,000$ & $96,930,400$ \\
2008 & $11,252,000,000$ & $131,082,000$ \\
2009 & $5,055,398,000$ & $144,650,000$ \\
2010 & $4,881,363,000$ & $144,350,000$ \\
2011 & $8,524,680,000$ & $173,950,000$ \\
2012 & $14,611,259,000$ & $213,600,000$ \\
2013 & $28,022,200,000$ & $194,800,000$ \\
2014 & $28,360,146,000$ & $259,820,450$ \\
\hline
\end{tabular}

Source: Annual reports.

\subsection{Specification of the Model}

Data were sourced from annual reports of Nigerian Breweries PLC and Lafarge Africa PLC publications, covering the period of 10 years (2005-2014), specifically, we have

Simple regression for hypothesis regression equation is written as:

$$
P A T=a_{0}+b 1 C S R K+U t
$$

PAT $=$ Profit after Tax

\section{CSR-K $=$ Corporate Social Responsibility Cost}

$\mathrm{Ut}=$ Error term or disturbance term assumed to have all the normality properties (i.e Constance variance and uncorrelated with the explanatory variable)

$\mathrm{a}_{0}=$ Intercept parameter

b1 $=$ Regression coefficient

Decision Rules are taken at 10\% significant levels.

\subsection{Analysis and Interpretation of Regression Results}

\subsubsection{Regression Results of Nigerian Breweries Plc}

The output of the regression result is presented in Table 3. The analysis shows that, CSRK variable has the correct signs (positive). The explanatory variable has significance probability of less than 0.10 . This implies that it is significant in the model at the $10 \%$ level. 
Table 3. OLS, using observations 2005-2014 $(\mathrm{T}=10)$

Dependent variable: PAT

\begin{tabular}{|c|c|c|c|c|c|c|}
\hline & Coefficient & Std. Error & t-ratio & $p$-value & & \\
\hline Const & $2.08992 \mathrm{e}+010$ & $4.93081 \mathrm{e}+09$ & 4.2385 & 0.00284 & & $* * *$ \\
\hline CSRK & 64.8126 & 30.9312 & 2.0954 & 0.06943 & & $*$ \\
\hline Mean dependent var & \multicolumn{2}{|c|}{$2.84 \mathrm{e}+10$} & S.D. dependent var & \multicolumn{3}{|c|}{$1.26 \mathrm{e}+10$} \\
\hline Sum squared resid & \multicolumn{2}{|c|}{$9.17 \mathrm{e}+20$} & S.E. of regression & \multicolumn{3}{|c|}{$1.07 \mathrm{e}+10$} \\
\hline R-squared & \multicolumn{2}{|c|}{0.354351} & Adjusted R-squared & \multicolumn{3}{|c|}{0.273644} \\
\hline $\mathrm{F}(1,8)$ & \multicolumn{2}{|c|}{4.390625} & P-value(F) & \multicolumn{3}{|c|}{0.069435} \\
\hline Log-likelihood & \multicolumn{2}{|c|}{-244.0166} & Akaike criterion & \multicolumn{3}{|c|}{492.0331} \\
\hline Schwarz criterion & \multicolumn{2}{|c|}{492.6383} & Hannan-Quinn & \multicolumn{3}{|c|}{491.3693} \\
\hline Rho & \multicolumn{2}{|c|}{0.401338} & Durbin-Watson & \multicolumn{3}{|c|}{0.865240} \\
\hline
\end{tabular}

From the regression output, the $\mathrm{R}=0.35$ shows that there is positive correlation between organization profitability and investment in corporate social responsibility activities.

The adjusted $\mathrm{R}^{2}$ or coefficient of determination of 0.27 shows that about $27 \%$ of the variation in PAT is explained by the predictor variable corporate social responsibility cost. The unexplained variation of about $73 \%$ is a result of variables outside the model. This implies that the model is good for strategic prediction.

The Durbin Watson Statistic of 0.865240 reveals an acceptable autocorrelation among the variables. Based on the above results, we conclude that there is significant relationship between corporate social responsibility and organization profitability.

\subsubsection{Regression Results of Lafarge Africa Plc}

Regression result in Table 4 shows that, CSRK variable has the correct signs (positive). The explanatory variable has significance probability of less than 0.10 . This implies that it is significant in the model at the $10 \%$ level.

Table 4. OLS, using observations 2005-2014 $(\mathrm{T}=10)$

Dependent variable: PAT

\begin{tabular}{|c|c|c|c|c|c|}
\hline & Coefficient & Std. Error & t-ratio & $p$-value & \\
\hline Const & $-1.2348 \mathrm{e}+09$ & $5.28362 \mathrm{e}+09$ & -0.2337 & 0.82108 & \\
\hline CSRK & 94.0968 & 33.0602 & 2.8462 & 0.02160 & $* *$ \\
\hline Mean dependent var & $1.25 \mathrm{e}+10$ & & S.D. dependent var & & $8.99 \mathrm{e}+09$ \\
\hline Sum squared resid & $3.62 \mathrm{e}+20$ & & S.E. of regression & & $6.72 \mathrm{e}+09$ \\
\hline R-squared & 0.503136 & & Adjusted R-squared & & 0.441028 \\
\hline $\mathrm{F}(1,8)$ & 8.100989 & & P-value(F) & & 0.021604 \\
\hline Log-likelihood & -239.3609 & & Akaike criterion & & 482.7218 \\
\hline Schwarz criterion & 483.3269 & & Hannan-Quinn & & 482.0579 \\
\hline Rho & 0.484402 & & Durbin-Watson & & 1.028595 \\
\hline
\end{tabular}

From the regression output, the $\mathrm{R}=0.50$ shows that there is positive correlation between organizational profitability and investment in corporate social responsibility activities.

The adjusted $\mathrm{R}^{2}$ or coefficient of determination of 0.44 shows that about $44 \%$ of the variation in PAT is explained by the predictor variable corporate social responsibility cost. The unexplained variation of about $56 \%$ is a result of variables outside the model. This implies that the model is good for strategic prediction.

The Durbin Watson Statistic of 1.028595 reveals a little autocorrelation among the variables. Based on the above results, we conclude that there is significant relationship between corporate social responsibility and organizational profitability. 


\section{Conclusions and Recommendations}

Organization is a legal person, with all the right accorded to her by law. Organization as a person has it economy and social life side by side. The economy life stressed on the financial well-being of the organization and it stakeholders. While the social life gives the human nature to organization. Human nature cares for one another. In the process of caring, the profitability of the organization should not be subjected to debate.

Board members may not know where to draw the line, when investing in CSR; this is responsible for the strategic misfit of most organization CSR activities resulting in wastage and loss. To guild board members in matters of CSR. The understanding of CSR orientation which established that, a good CSR must promote profitability, trusteeship and quality of life is very vital. The principle of sustainability, accountability and transparency must be upheld in all CSR decision.

In the words of Amaeshi (2011), "The ultimate goal of a true CSR orientation is to contribute to a better society. And CSR affords firms and managers the opportunity to adjust their means of production in way that given then competitive advantage and enhance their long term profitability".

The analyses of the regression result of Nigerian Breweries PLC and Lafarge Africa PLC shows that, there is a positive correlation between organizational profitability and investment in CSR. But the coefficient of determination established that more than $50 \%$ of the unexplained variable is a result of variables outside the model. This implies that the model is good for strategic prediction. Not suitable for tactical prediction. Therefore CSR is a long-term investment or commitment which all organization should undertake in line with their corporate mission and vision.

It is too dangerous to flout social responsibility, it may be convenient in the short-term but too dangerous in the long-term.

In light of the findings of the research the following recommendations where made:

- CSR should be viewed as an integral part of the organization decisions and strategy.

- Organization should constitute committee to oversee their social responsibility activities, while taking into consideration the organization mission and vision.

- Companies should involve the stakeholders to formulate and implement social responsibility programs that address both parties mutual interest.

- Companies CSR should be flexible, dynamic and marketable.

- CSR should be strategically carried out without endangering corporate survival that is CSR should never over-shadow profit maximization objectives.

\section{References}

Agu, C. N. (2003). Management an introductory text. Owerri, Resource Development centre.

Agulanna, C. E., \& Madu, C. M. (2008). Business policy the face of strategic management (book 1). Owerri, Joe Mankpa Publishers.

Amaesh, K. (2011). Corporate social responsibility is more than philanthropy. Business Day, 14.

Amaeshi, K. M., Bongo, C. A., Ogbechie, C., \& Amao, O. O. (2006). Corporate Social Responsibility (CSR) in Nigeria: Western mimicry or indigenous practices? ICCSR Research Paper Series.

Brown, J. B., \& Clow, E. J. (2008). Introduction to Business. New York, the McGraw-Hill Companies, Inc.

Chikwendu, C. O. (2011). Business policy and strategic management. Owerri, Ambix Printers Nig.

Chikwendu, C. O., Nwosu, A. N., \& Chima-Nwaneri, C. (2011). Business Ethics and Social Responsibility. Owerri, Ambix Printers Nig.

Emezi, C. N. (2011). SWOT of Nigeria business environment. Association of African Entrepreneur, Ghana. Retrieved from http://www.aaeafrica.org/cgi-bin/resources/index.cgi?action=downloads\&cat=Nigeria

Emezi, C. N. (2014). Corporate social responsibility (CSR) and business sustainability: HR's leadership role. Unpublished MBA-thesis. Lagos, National Open University of Nigeria.

Friedman, M. (1962). Capitalism and Freedom. Chicago: University of Chicago.

David, G., \& Gùler, A. (2010). Corporate social responsibility: Part 1 principles, stakeholders, and sustainability. New York: Ventus publishing ApS. 
Drucker, P. F. (1986). Management Task, Responsibilities and Practice. Cavaye Place London: Pan Books Limited.

Haberberg, A., \& Mulleady, F. (2004). Understanding the practice of corporate social responsibility: A research agenda. Proceedings of British Academy of Management Annual Conference St Andrews, September.

Higgins, M. J. (1991). The management challenge. New York: Macmillan Publishing Company.

Kotler, P. (2005). Marketing Management (11th ed.). New Delhi: Prentice Hall London.

Wolf, M. (2001). Sleep-walking with the enemy: Corporate Social Responsibility distorts the market by deflecting business from its primary role of profit generation. London: Financial Times.

\section{Copyrights}

Copyright for this article is retained by the author(s), with first publication rights granted to the journal.

This is an open-access article distributed under the terms and conditions of the Creative Commons Attribution license (http://creativecommons.org/licenses/by/3.0/). 